\title{
THE IMPACT OF CHRONIC OBSTRUCTIVE LUNG CLINICAL PATHWAY IMPLEMENTATION ON READMISSION: A SYSTEMATIC REVIEW
}

\author{
Joan Puspita Tanumihardja, Atik Nurwahyuni \\ Masters Program in Hospital Administration Study, Universitas Indonesia
}

\begin{abstract}
Background: Chronic obstructive pulmonary disease (COPD) is the $4^{\text {th }}$ leading cause of death in the world. The COPD prevalence in Indonesia was 3.7\% affecting around 9.2 million population, with East Nusa Tenggara Province ranked first. COPD is expected to increase in the coming years due to the increasing of smoker and elderly population. Although it cannot be cured, the general practice of COPD aims to reduce symptom, prevent exacerbation of repetition, improve lung function, and improve the quality of life. Clinical pathway is a clinical management in a multidisciplinary hospital to increasing clinical outcomes and reducing cost by reduce the variations in services. This study aimed to systematically review the impact of COPD clinical pathway implementation on readmission.

Subjects and Method: A systematic review was conducted through electronic databases, including PubMed and Scopus. The keywords used were "COPD" AND "clinical pathway" AND "readmission". The articles were collected between 2010 and 2019. The data were analyzed by PRISMA flow diagram. Results: The implementation of clinical pathway in hospital on the management of COPD showed various outcomes. Four of 6 study showed that the implementation of clinical pathways was associated with decreased readmission rate of 30 days to 90 days and mortality rate. Two other studies did not show significant decrease in readmission and mortality rates.
\end{abstract}

Conclusion: The implementation of clinical pathway for COPD is associated with decreased readmission.

Keywords: chronic obstructive pulmonary disease, clinical pathway, readmission

\section{Correspondence:}

Joan Puspita Tanumihardja. Masters Program in Hospital Administration Study, Universitas Indonesia. Email: genubies@gmail.com. Mobile: 08111884138.

\section{BACKGROUND}

Chronic Obstructive Pulmonary Disease (COPD) is the fourth leading cause of death in the world. The prevalence in Indonesia reaches $3.7 \%$ or around 9.2 million people in NTT province who was in the first rank (Balitbangkes, 2013). Chronic obstructive pulmonary disease (COPD) is one of a group of non-communicable diseases that has become a public health problem in Indonesia. This is due to the increased life expectancy and the higher exposure to risk factors, such as host factors that are suspected to be associated with COPD incidents, the increasing number of smokers, especially in the younger age group, and air pollution indoors and outdoors and in the workplace (Ministry of Health, 2008). Basic Health Research in 2013 data showed the prevalence of COPD increases according to the characteristics of increasing age, male gender, rural areas, low education.

The economic burden for COPD is quite significant with estimated direct and indirect costs of COPD in America reaching 49.9 trillion dollars in 2010 (Guarascio, 2013). This is related to the high incidence of COPD replication or exacerbation which causes a high burden of COPD on the health system (GOLD, 2018).

Clinical pathway is the flow of clinical management in multidisciplinary hospitals that is used to reduce variation in services 
thereby increasing clinical outcomes and reducing costs. This study aimed to determine the impact of the application of clinical pathway in chronic obstructive pulmonary disease on the level of patient readmission.

\section{SUBJECTS AND METHOD \\ 1. Study Design \\ A systematic review was carried out with the PRISMA instrument using the PRISMA checklist which systematically filters articles found in searches. In the first stage, the search for publication articles was done by opening the Pubmed and Scopus databases through http//remote.lib.ui.ac.id website.}

\section{Inclusion and Exclusion Criteria}

Inclusion criteria used in the search included 1) English-language articles, 2) documents in the form of articles or reviews, 3) publishing articles between 2009 and 2019, 4) types of open access publications. The keywords used are COPD or chronic obstructive pulmonary disease, clinical pathway or integrated clini- cal pathway and readmission. Exclusion criteria were articles in languages other than English, publication years outside the 20092019 time span and limited access.

In a search with keywords COPD or chronic obstructive pulmonary disease, 37,868 articles were found and then the keyword of clinical pathway or integrated clinical pathway was added so that it decreased to 399 articles and finally the keyword readmission found 17 articles. The article was then screened from the relevance of the abstract and contents of the journal so that the final stage was obtained by 6 articles. The PRISMA flow diagram was attached in the figure below.

\section{Data Extraction}

Data extraction was done by analyzing the article title, place of study, year of study, study variables and study results. The results of data extraction can be seen in the table below.
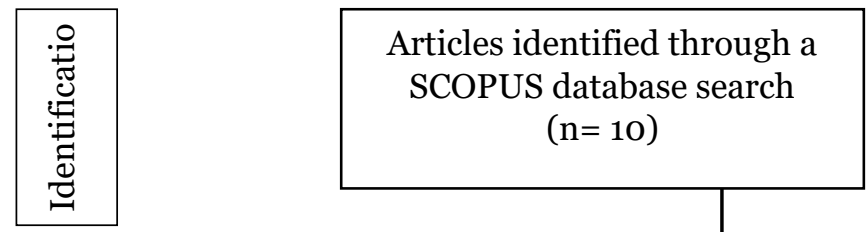

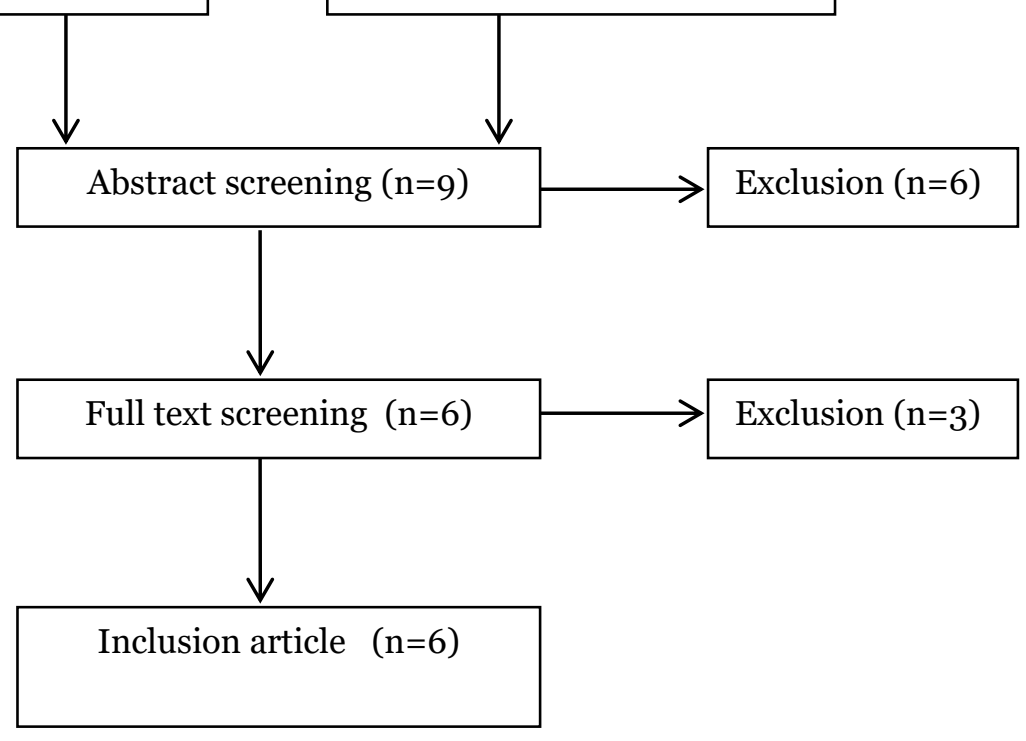

Figure 2. PRISMA flow diagram

The $6^{\text {th }}$ International Conference on Public Health Best Western Premier Hotel, Solo, Indonesia, October 23-24, 2019 | 593 https://doi.org/10.26911/the6thicph-FP.05.04 


\section{RESULTS}

Table 1. Articles reviewed in this study

\begin{tabular}{|c|c|c|c|c|c|c|c|}
\hline No & Title & Author & $\begin{array}{l}\text { Place of } \\
\text { Study }\end{array}$ & $\begin{array}{l}\text { Study } \\
\text { Method }\end{array}$ & $\begin{array}{c}\text { Total } \\
\text { Sample }\end{array}$ & $\begin{array}{c}\text { Study } \\
\text { Variable }\end{array}$ & Results \\
\hline 1 & $\begin{array}{l}\text { A comprehensive care } \\
\text { plan that reduces } \\
\text { readmissions after } \\
\text { acute exacerbations of } \\
\text { COPD }\end{array}$ & $\begin{array}{l}\text { Ohar, et al } \\
(2018)\end{array}$ & $\begin{array}{l}\text { University } \\
\text { Hospital, } \\
\text { USA }\end{array}$ & $\begin{array}{l}\text { Retrospective } \\
\text { obstetric } \\
\text { analysis }\end{array}$ & 1274 & $\begin{array}{l}30 \text { day } \\
\text { readmission due } \\
\text { to all causes }\end{array}$ & $\begin{array}{l}\text { 30-day readmission in the group that received the } \\
\text { AECOPD care plan was lower by } 16 \%\end{array}$ \\
\hline 2 & $\begin{array}{l}\text { Evaluation of care } \\
\text { bundles for patients } \\
\text { with COPD : a multisite } \\
\text { study in the UK }\end{array}$ & $\begin{array}{l}\text { Morton et al. } \\
\text { (2019) }\end{array}$ & $\begin{array}{l}\text { Hospital, } \\
\text { England } \\
\text { dan Wales }\end{array}$ & $\begin{array}{l}\text { Mixed method } \\
\text { research, } \\
\text { controlled } \\
\text { before and } \\
\text { after research }\end{array}$ & $\begin{array}{l}31 \\
\text { hospitals }\end{array}$ & $\begin{array}{l}28 \text { day } \\
\text { readmission }\end{array}$ & $\begin{array}{l}\text { There is no evidence of differences in readmission } \\
\text { between groups that received care bundles } \\
\text { compared to those who did not }\end{array}$ \\
\hline 3 & $\begin{array}{l}\text { COPD exacerbation } \\
\text { care bundle improves } \\
\text { standard of care, length } \\
\text { of stay and readmission } \\
\text { rates }\end{array}$ & $\begin{array}{l}\text { Parikh et al } \\
(2016)\end{array}$ & $\begin{array}{l}\text { University } \\
\text { Hospital, } \\
\text { USA }\end{array}$ & $\begin{array}{l}\text { Prospective } \\
\text { cohort } \\
\text { analysis }\end{array}$ & 44 & $\begin{array}{l}30 \text { day } \\
\text { readmission }\end{array}$ & $\begin{array}{l}\text { there was a significant decrease in the 30-day } \\
\text { readmission rate }\end{array}$ \\
\hline 4 & $\begin{array}{l}\text { Impact of clinical } \\
\text { pathway on clinical } \\
\text { outcomes in the } \\
\text { management of COPD } \\
\text { exacerbation }\end{array}$ & $\begin{array}{l}\text { Ban et al. } \\
(2012)\end{array}$ & $\begin{array}{l}\text { University } \\
\text { Hospital, } \\
\text { Malaysia }\end{array}$ & $\begin{array}{l}\text { Non- } \\
\text { randomized } \\
\text { prospective } \\
\text { study }\end{array}$ & 193 & $\begin{array}{l}30 \text { day } \\
\text { readmission }\end{array}$ & $\begin{array}{l}\text { There was no difference in readmission rates } \\
\text { between } \mathrm{CP} \text { and non } \mathrm{CP} \text { groups }\end{array}$ \\
\hline
\end{tabular}

The $6^{\text {th }}$ International Conference on Public Health Best Western Premier Hotel, Solo, Indonesia, October 23-24, $2019 \mid 594$ https://doi.org/10.26911/the6thicph-FP.05.04 


\begin{tabular}{|c|c|c|c|c|c|c|c|}
\hline 5 & $\begin{array}{l}\text { Impact of a care } \\
\text { pathway for COPD on } \\
\text { adherence to guidelines } \\
\text { and hospital } \\
\text { readmission : a cluster } \\
\text { randomized trial }\end{array}$ & $\begin{array}{l}\text { Vanhaecht et } \\
\text { al. (2016) }\end{array}$ & $\begin{array}{l}\text { General } \\
\text { hospitals } \\
\text { in } \\
\text { Belgium, } \\
\text { Italy and } \\
\text { Portugal }\end{array}$ & RCT cluster & 342 & $\begin{array}{l}30 \text { day } \\
\text { readmission }\end{array}$ & The 30-day readmission rate is statistically lower \\
\hline 6 & $\begin{array}{l}\text { Impact of a COPD } \\
\text { discharge care bundle } \\
\text { on readmissions } \\
\text { following admissions } \\
\text { with acute exacerbation } \\
\text { : an interrupted time } \\
\text { analysis }\end{array}$ & $\begin{array}{l}\text { Laverty et al. } \\
(2014)\end{array}$ & $\begin{array}{l}\text { General } \\
\text { Hospital, } \\
\text { England }\end{array}$ & $\begin{array}{l}\text { Interrupted } \\
\text { time analysis }\end{array}$ & 9 hospitals & $\begin{array}{l}30 \text { day } \\
\text { readmission }\end{array}$ & $\begin{array}{l}\text { There was a decrease in the } 30 \text {-day readmission } \\
\text { rate but it was not significant }\end{array}$ \\
\hline
\end{tabular}

The $6^{\text {th }}$ International Conference on Public Health Best Western Premier Hotel, Solo, Indonesia, October 23-24, 2019 | 595

https://doi.org/10.26911/the6thicph-FP.05.04 


\section{DISCUSSIONS}

Although it cannot be cured, the general practice of COPD aimed to reduce symptoms, prevent exacerbations of repetition, improve lung function and improve the quality of life of sufferers. Clinical pathway is a clinical management flow in a multidisciplinary hospital that is used to reduce variations in services thereby increasing clinical outcomes and reducing costs.

The burden of COPD on the health system was directly related to the increase in COPD exacerbations. The cost of health services for COPD increased due to an increase in LOS 4.5 - 8.8 days and COPD was in the fourth rank as the main cause of 30 day readmissions (Parikh, 2016).

The reason for readmission for patients can be specifically related to COPD by $27.6 \%$ or other causes such as comorbidity. But research showed only $50.6 \%$ of readmission due to causes related to breathing. The frequency of readmission due to COPD was higher in patients receiving discharge plans without homecare services (Shah, 2014)

In 2 research articles located in America found the following results: Ohar et al (2018) found that patients who received treatment plans according to the clinical flow had a 22\% lower chance of specific COPD readmission at 90 days but not significant for 30 days. The presence of patients in the follow-up care control plan in the clinic also influences readmission. Ohar et al. (2018) mentioned that the delay and incompleteness of pulmonary rehabilitation might explain the decline in COPD specific readmission rates at 90 days instead of 30 days. Research by Parikh et al. (2016) also found a significant reduction in 30 and 60 day readmission rates with the use of standardized COPD modules in patient care. Furthermore Parikh, et al concluded that the characteristics of patients with lower economic and educational levels would be more likely to experience readmission. This was related to the lower level of health knowledge when it was associated with post-hospitalization followup such as the use of bronchodilators which was not appropriate.

Research done by Vanhaecht et al. (2016) found differences in the level of 30day readmission between the $\mathrm{CP}$ and non-CP groups. In the study, it was concluded that the reduction in 30-day readmission rate was closely related to the management of patients while being treated in a hospital based on $\mathrm{CP}$. It was found in the study that a total of 17 of 342 patients (6: 100) did not experience readmissions, which when it was juxtaposed with WHO data, it obtained the potential for a reduction in readmissions in the world by 4 million cashus.

Ban et al (2012) conducted a study in Malaysia and found no difference in the level of readmission in COPD patients who received management according to the clinical pathway compared to those who did not. This was related to the inconsistency of Malaysian national guidelines and their application in daily practice and the low level of compliance with $\mathrm{CP}$ implementation so that the clinical outcomes of patients also vary.

In the Morton et al. (2019) study, there was also no change in the level of readmission at the study sites that applied the care bundle. The qualitative results of the study indicated the weak implementation of care bundle by clinical staff and also the possibility of applying the same clinical management in the implementation location and comparison because there were differences in naming only for clinical management.

In 1 study by Laverty et al. (2015), it was found that there was a decrease in the reading level of 30 days but was not significant. However, clinicians in this study estimated the positive impact of its application on the level of readmission. The applica- 
tion of care bundles played a role in focusing the most important interventions on COPD management, namely medical rehabilitation and efforts to stop smoking behavior.

Press et al. (2019) stated that interventions to reduce readmission should be developed and not just focus on COPD therapy. Patient education and lifestyle modification through continued facilitation in outpatient clinics can have an impact on the overall quality of life and health of people with COPD. The application of non-pharmacological management in COPD clinical pathway was still low, however non-pharmacological management played an important role in education such as smoking cessation.

In addition to achieving the goal of improving health, there were other things that might affect the readmission rate of COPD patients in countries such as America. The purpose of applying clinical pathway/care bundle/care pathway for the diagnosis of Chronic Obstructive Pulmonary Disease (COPD) was as part of a government program (Ohar et al., 2018) to reduce the level of readmission of patients to the hospital. Hospital Readmissions Reduction Program (HRRP) was an American government program to support the national goal of improving health services that connected payment with the quality of health facility services with COPD included as one of the 6 diagnoses and programmed actions (CMS, 2016).

Punishment provided by the health financing system in America included a 3\% reduction in claims if the hospital cannot reach the level of readmission the government expects (Shah, 2015). However this can be biased in COPD clinical governance; hospitals that serve patients at greater risk (lower education) may be subject to unfair penalties and may also avoid in treating these patients (Shah, 2015).
Application of clinical pathway Chronic Obstructive Pulmonary Disease has the potential to reduce the level of readmission and other outcomes such as death rates, length of stay and costs. To improve good clinical outcomes requires a clinical pathway/care bundle that was well organized and implemented. The components in the clinical pathway/care bundle that seem to have an impact were those that were arranged up to the discharge bundle with an emphasis on education and rehabilitation after treatment in the hospital. The availability of data that was still small and the results were still varied showed the importance of other studies conducted in the future, especially large-scale RCT research.

\begin{tabular}{l}
\hline REFERENCES \\
\hline Badan Penelitian dan Pengembangan Kese- \\
hatan Kementrian Kesehatan RI \\
(2013). Riset Kesehatan Dasar 2013 \\
(Basic Health Research in 2013). \\
http://www.depkes.go.id/resources/- \\
download/general/Hasil\%2oRiskesdas \\
\%202013.pdf. Accessed in August 2019. \\
Ohar JA, Loh CH, Lenoir KM, Wellsc BJ, \\
Peters SP (2018). A Comprehensive \\
Care Plan That Reduces Readmissions \\
After Acute Exacerbations of COPD. \\
Respiratory Medicine; 141: 20-25. \\
Parikh R, Gshah T, Tandon R (2016). COPD \\
Exacerbation Care Bundle Improves \\
Standard Of Care, Length Of Stay, And \\
Readmission Rates. International \\
Journal Of COPD; 11: 577-283. \\
Morton K, MacNeill S, Sanderson E, Dixon P, \\
King A, Jenkins S, et al (2019). \\
Evaluation of care bundles for patients \\
with chronic obstructive pulmonary \\
disease (COPD): a multisite study in the \\
UK. BMJ Open Respiratory Research; \\
6:eooo425. doi: 10.1136. \\
Vanhaecht K, Lodewijckx C, Sermeus W, \\
Decramer M, Deneckere S, Leigheb F,
\end{tabular}


Boto P, et al (2016). Impact of a care pathway for COPD on adherence to guidelines and hospital readmission: a cluster random trial. International Journal of COPD; 11: 2897-2908.

Laverty AA, Elkin SL, Watt HC, Millett C,Restrick LJ, Williams S, et al. (2015) Impact of a COPD Discharge Care Bundle on Readmissions following Admission with Acute Exacerbation: Interrupted Time Series Analysis. PLoS ONE 10(2): eo116187. doi:10.1371/journal.pone.0116187

Ban A, Ismail A, Harun R, Rahman AA, Sulung S, Mohamed AS (2012). Impact of clinical pathway on clinical outcomes in the management of COPD exarcebation. BMC Pulmonary Medicine 2012, 12:27.

Global Initiative For Chronic Obstructive Lung Disease (2018). Global Strategy For The Diagnose, Management, And Prevention Of Chronic Obstructive Pulmonary Disease: 2018 Report.

Guarascio AJ, Ray SM, Finch CK, Sel TH (2013). The clinical and economic burden of chronic obstructive pulmonary disease in the USA. Clinico Eco- nomics and outcomes research 2013; 5 : 235-245.

Centers for Medicare \& Medicaid Services (2016). Hospital Readmissions Reduction Program (HRRP). https://www.cms.gov/medicare/medicare-fee-forservice-payment/acuteinpatientpps/readmissions-reduction-program.html

Kementerian Kesehatan Republik Indonesia (2008). Kepmenkes No. 1022/MENKES/SK/XI/2008 Tentang Pedoman Pengendalian Penyakit Paru Obstruktif Kronik (Minister of Health Decree No. 1022/MENKES /SK/XI/2008 concerning Guidelines for Chronic Obstructive Pulmonary Disease Control).

Shah T, Churpek MM, Perraillon MC, Konetzka TK (2015). Understanding why patients with COPD get readmitted. CHEST 2015; 147(5): $1219-1226$.

Press VG, Au DH, Bourbeau J, Dransfield MT, Gershon AS, Krishnan J, et al. (2019) Reducing Chronic Obstructive Pulmonary Disease Hospital Readmission: An Official American Thoracis Society Workshop Report. Annals ATS. 16(2): 161-170. 